\title{
POPULATION CONCENTRATION IN LESS DEVELOPED COUNTRIES: NEW EVIDENCE
}

F. Landis MacKellar

International Institute for Applied Systems Analysis

Laxenburg, Austria

Daniel R. Vining, Jr.

Population Studies Center, University of Pennsylvania

Philadelphia, PA, USA

RR-96-1

January 1996

Reprinted from Papers in Regional Science: The Journal of the RSAI, 74(3):259-293 (1995).

INTERNATIONAL INSTITUTE FOR APPLIED SYSTEMS ANALYSIS Laxenburg, Austria 
Research Reports, which record research conducted at IIASA, are independently reviewed before publication. Views or opinions expressed herein do not necessarily represent those of the Institute, its National Member Organizations, or other organizations supporting the work.

Reproduced with permission from Papers in Regional Science: The Journal of the RSAI, 74(3):259-293, 1995.

Copyright (C)1995 Regional Science Association International

All rights reserved. No part of this publication may be reproduced or transmitted in any form or by any means, electronic or mechanical, including photocopy, recording, or any information storage or retrieval system, without permission in writing from the copyright holder.

Printed by Novographic, Vienna, Austria. 


\title{
Preface
}

The growth of "mega-cities" in developing countries is a source of concern. This paper treats a closely related topic, the increasing concentration, through rural-urban migration, of population in "core regions," which accounts for disproportionate shares of population and economic activity. In the industrialized countries a trend toward deconcentration, i.e., net outmigration from core regions, has been evident since the censuses of the 1970s. This reversal of national migration patterns often first asserted itself at a level of development corresponding to per capita GDP of 5,000 US dollars (1985 terms).

In this paper, Landis MacKellar of the Population Project and D.R. Vining, Jr. of the Population Studies Center of the University of Pennsylvania review evidence from the 1990 round of censuses in less developed countries. While there have been some notable reversals during the last intercensal interval (most notably, net out-migration from the regions surrounding Mexico City and Bangkok), they find that there is nothing inevitable about the commencement of population deconcentration at any given level of development. The share of the core region can continue to grow long after per.capita GDP exceeds US $\$ 5,000$. This suggests that some LDC urban agglomerations may reach sizes that are astonishing by current standards.

In combining demographic, geographic, and economic reasoning, the paper is typical of IIASA's multidisciplinary research focus. In making available, in summary form, data on population distribution in LDCs during the postwar period, it also reflects the Population Project's continuing emphasis on dissemination and analysis of basic demographic data.

\author{
Wolfgang Lutz \\ Leader \\ Population Program
}




\title{
POPULATION CONCENTRATION IN LESS DEVELOPED COUNTRIES: NEW EVIDENCE
}

\section{F. Landis MacKellar}

International Institute for Applied Systems Analysis (IIASA)

\section{A-2361 Laxenburg}

\section{Austria}

\section{Daniel R. Vining, Jr.}

Population Studies Center

University of Pennsylvania

Philadelphia, PA 19104

USA

\begin{abstract}
Economic theory associates the increase in population concentration, i.e., the proportion of national population residing in the core economic region, with scale and agglomeration economies. Wheaton and Shishido (1981) estimated that these persist until real per capita national income reaches 5,000 1985 U.S. dollars (USD). After this point in a country's economic development, they predicted, population redistribution towards the core region will cease and the proportion of national population residing in the core region will commence to decline. The experience of developed countries (DCs) in the 1970 s and 1980s broadly conformed to this pattern, albeit with exceptions. Evidence from less developed countries (LDCs) through the 1980 round of censuses led Vining (1986) to propose a weakened version of the USD 5,000 rule in which this point is characterized only by a slowing of rate of population re-distribution towards the core, not by an outright reversal. This paper updates previously reported trends in population redistribution in LDCs and reports on many new countries. Taken as a whole, post-war data reinforce the need for caution of the sort expressed by Vining. While there is a weak negative correlation between the rate of net migration into the core region and per capita income, the share of population residing in the core region may continue to rise even when per capita income has grown to well beyond USD 5,000
\end{abstract}

Men, thinly scattered, make a shift, but a bad shift, without many things. A smith is ten miles off: they do without a nail or a staple. A taylor is far from them: they'll botch their clothes. It is being concentrated which produces high convenience. (Boswell 1786, p. 169)

\section{INTRODUCTION}

Concern over Third World city growth arises not from urbanization per $s e$, but rather from the spatially unbalanced character of the present urbanization process. As the United Nations Population Division (1993) and others have noted, current demographic trends are rapidly giving rise to "mega-cities" whose absolute size, rate of growth and exaggerated primacy are sources 
of concern from the standpoint of economic and environmental sustainability. While policy makers in less developed countries (LDCs) disagree on the consequences of the size and increase of their national populations, they are almost unanimous in condemning its spatial distribution. Thus, most of the LDCs on which information is available in the Population Policy Data Bank maintained by the United Nations Population Division are, or at least claim to be, implementing policies to slow the rate of primate city growth.

This paper does not treat directly the "mega-city" phenomenon, but concerns itself with a closely related subject: the continuing redistribution of populations towards "core regions" of LDCs, that is, regions (usually but not always containing the capital city) accounting for a disproportionate share of population and economic activity. Due to urban sprawl and the resulting under-bounding of city administrative boundaries, the population of the core region is frequently a more accurate measure of the size of the primate urban agglomeration than is city size itself.

The standard economic model of population redistribution and development (Alperovitch 1992; Petrakos 1992; Parr 1985; Alonso 1971; Mera 1973) starts with the location decision of the firm in the face of scale and agglomeration (localization and urbanization) economies (Soroka 1994). As resources, including human resources, are increasingly concentrated in the core region, the rate of return to such resources is boosted further, promoting yet further redistribution towards the core. Eventually, scale and agglomeration economies will be exhausted, perhaps in conjunction with diseconomies of congestion and the ecological ill-effects of over-urbanization in the primate city (Richardson 1989; Bartone 1991), at which point the proportion of the national population residing in the core region will begin to decline. The role of social, cultural and political factors such as ethnic diversity and the distribution of power between core and peripheral regions has also been cited by some researchers (Mutlu 1989; Petrakos and Brada 1989).

\section{THE 5,000 DOLLAR RULE(S)}

Wheaton and Shishido (1981) estimated a model which suggested rising concentration of urban population into a few primate metropolitan areas, up to a level of national development corresponding to a per capita income level of roughly 5,000 1985 U.S. dollars (USD; as a benchmark, this was approximately the level of income in Korea in the second half of the 1980s - Wheaton and Shishido cited a cutoff of 2,000 1970 USD, which corresponds to approximately 5,200 1985 USD). Citing "a consistent and plausible relationship between economic development and urban concentration," Wheaton and Shishido concluded that the course of population redistribution is entirely predictable: "Urban concentration must increase with the level of development, until the latter approaches USD 2,000 [USD 5,000 in 1985 terms]. After that, spatial decentralization sets in" (Wheaton and Shishido 1981, p. 29).

Vining and his associates examined, in a series of articles, trends in the distribution of total, not just urban, populations in DCs. They found that in the 1970s, virtually all DCs experienced, for the first time in the historical record, either radically lower rates of net migration towards or actual net migration away from core regions (Vining and Kontuly 1978; Vining and Pal- 
lone 1982). Consistent with the rule proposed for urban populations by Wheaton and Shishido, this tended to occur at a per capita GDP level of approximately USD 5,000, albeit with exceptions, such as Japan, in which concentration continued to rise long after national income had reached USD 5,000. Population redistribution trends in the LDCs through the 1980 round of censuses were then examined by Vining (1986), who concluded as follows:

The basic pattern first observed in Western countries, i.e., of a close association between economic development and population concentration, appears to be being followed in an entirely predictable fashion by non-Western countries.

He added, however, a caveat:

\begin{abstract}
Indeed, the preponderance of the evidence from those countries studied here . . . suggests that only a slackening of the pace of population redistribution pace towards the core can be expected when this level of development [i.e., the inflection point found by Wheaton and Shishido] is reached, not an actual de-concentration. (Vining 1986, p. 18)
\end{abstract}

Nor has the course of population concentration in DCs since 1980 been straightforward (Cochrane and Vining 1986; Champion 1994): Japan, for example, having experienced population deconcentration during the 1970s, experienced "reconcentration," especially in the Tokyo metropolitan region, during the early 1980s (Tsuyo and Kuroda 1989). However, Champion (1989, p. 241) concluded from nine DC case studies that the "the main weight of the evidence" favored the interpretation that the stalling of deconcentration in some DCs in the 1980s was an anomaly, not the reversal of a trend.

Thus, we have three USD 5,000 rules:

(a) the original Wheaton-Shishido rule, that urban population concentration rises until national GDP reaches USD 5,000, at which point it begins to fall;

(b) ditto for total population; and

(c) ditto except that net migration into the core region does not actually turn negative at USD 5,000; it merely declines dramatically.

Of these, it is the second, which is most comprehensive and least equivocal, to which we will refer as "the" USD 5,000 rule.

Even in weakened form, the USD 5,000 rule is by no means universally accepted. A plausible optimistic view (e.g., Critchfield 1979, 1981), holds that the DC-paradigm, in which redistribution trends are driven by agglomeration and scale economies in industry, is inappropriate to those developing countries (such as Bangladesh, China and others) where a dominant rural sector is characterized by rapid technical progress, a good supply of skilled workers and the potential for reaping agriculture-based cconomies of scale in transport, communication, storage, research and development, service extension and the like. The combination of lower rural fertility and higher rural incomes in consequence of improved agricultural productivity is, in this interpretation, giving rise to unprecedented rural welfare gains, which will be reflected in diminished rates of rural-urban migration and augmented rates of return migration at per capita income levels far below USD 5,000. 
Another view, often expressed by researchers at the World Bank (e.g., World Bank 1986), is based on the familiar neoclassical push-pull model of migration and emphasizes the role of price distortions and superior access to amenities, both often grouped together under the rubric "urban bias," privileging the urban population. Thus, many aspects of structural adjustment - devaluation of over-valued exchange rates that favor urban consumers at the expense of rural producers, dismantlement of state agricultural marketing boards with their artificially low purchasing prices, elimination of subsidies in the pricing of urban services and infrastructure and so on - should slow rural-urban migration. Gilbert (1993) attributes the reduction in Third World urban growth rates observed during the 1980s to three factors:

(a) changes in the terms of trade that favored tradeable goods at the expense of non-tradeables, and the switch from import-substituting to export-promoting industrial strategy - this is the bright side of the World Bank model;

(b) recession, the collapse of urban employment and immiseration of substantial portions of the urban population; this is the dark side (c.f., Gilbert 1994); and

(c) the transformation of primate cities into more dispersed, polycentric urban forms.

\section{NEW EVIDENCE}

In Table 1 of Appendix A, the LDC census data presented by Vining (1986) are updated through the 1990 round of censuses, and data for many new countries are presented. The chosen index of population redistribution is the difference $\left(\times 10^{3}\right)$ between the core region's exponential population growth rate and that of the country as a whole. On the assumption that core region and national rates of natural increase are equal, this difference is equal to the rate of net migration into the core region. In most LDCs, rates of natural increase are lower in core regions because of rural-urban fertility differentials; the difference between core and peripheral region population growth rates is, however, aominated by the net migration rate.

The net migration rate is a place-specific characteristic; it does not refer to a particular individual behavior and thus does not have the same neat probabilistic interpretation of a mortality rate or a fertility rate. Nonetheless, at the risk of some looseness of usage, we employ the term "net migration rate into the core region" as opposed to more cumbersome alternatives such as "rate of net migration experienced by the core region." Estimates of out-migration rates in LDC peripheral regions, whether obtained indirectly from origin and duration of residence questions on census questionnaires, or directly through population registers or sample surveys, would have the desired probabilistic interpretation; however, these are not available broadly enough to make possible a comprehensive international survey of the sort presented here.

The data source for estimates of per capita income is the 1993 update of the Penn World Table (Mark 5.1) discussed by Summers and Heston (1993) and available from the National Bureau for Economic Research. The statistic 
reported is inter-censal average income, estimated as the mean of the two endpoints.

\section{Countries previously covered}

Countries in which previously observed population redistribution trends continued. New censuses in those countries that were previously covered indicate that significant population concentration continues to occur in Bangladesh (1981-91, per capita income of USD 1,122 during the inter-censal interval), Colombia (1973-85, USD 2,639), Ecuador (1982-90, USD 2,968), India (198191, USD 929), Egypt (1976-86, USD 1,568), Philippines (1980-90, USD 1,810) and Turkey (1980-85, USD 2,956 and 1985-90, USD 3,385).

Net migration into the core region continues to be almost nil in Ireland (1981-86, USD 7,054 and 1986-91, USD 8,112) and Uruguay (1975-85, USD $3,898)$; and to be modest at a surprisingly low level of per capita income in Tunisia (1975-84, USD 2,334). International out-migration, which rright invalidate the standard economic model of population concentration, is a major demographic factor in Ireland and at least a significant one in Tunisia. The previously observed deceleration in the rate of net migration into the Santiago region continued in Chile (1982-92, USD 3,653), and Peru (1981-93, USD 2,503) appears to be undergoing a similar process.

The population deconcentration that first manifested itself in Argentina at a per capita income level fairly close to USD 5,000 continued (1980-91, USD 4,129). The long established deconcentration trends in Israel and Sri Lanka, unusual cases whose peculiarities were discussed by Vining (1986), continued during the 1970s (1972-83, USD 7,358) and 1980s (1981-91, USD 2,018), respectively.

The model according to which improvements in rural living standards alleviate migratory pressures early in the development process would seem to be particularly relevant to Southeast Asia, but the evidence is mixed. In South Korea, where the region around Seoul has traditionally exerted an extraordinarily strong attraction, concentration continued in the last two intercensal intervals (1980-85, USD 3,695 and 1985-90, USD 5,238). In Malaysia (1980-90, USD 4,338), there is no evidence of a deceleration of net migration into the core region. We were unable to obtain sufficiently detailed census data to present an update for Indonesia (1981-90, USD 1,700). It appears, however, that while the growth rate of Jakarta itself decelerated (from 3.4\% per year in $1971-81$ to $2.4 \%$ in 1981-90), population growth in the surrounding areas of Bogor, Bekasi and Tamnggerang was on the order of $5 \%$ per year (Hull 1994). In view of the deceleration of population growth observed in Yogyakarta, and in East and Central Java, due in part to rapid fertility decline and in part to out-migration, it appears safe to conclude that population concentration continued.

Countries in which there has occurred a reversal of previously observed population redistribution trends. In Thailand (1980-92, USD 2,839), the latest census reveals modest net out-migration from Bangkok and its environs. This would appear to be a clear exception to the USD 5,000 rule, and it seems plausible that rising environmental costs and disamenities are playing a role. 
The USD 5,000 rule in its naive form - a decisive reversal of net migration trends occurring at almost precisely the moment GDP passes USD 5,000 is illustrated by the cases of Greece (1981-91, USD 6,278), Mexico (1980-90, USD 5,543) and, less dramatically, Portugal (1981-90, USD 5,809). In the case of Mexico City, research suggests that deterioration of the urban environment is a contributing factor (Izazola and Marquette 1994).

Spain (1981-90, USD 8,492) exemplifies Vining's weakened interpretation of the rule: the net migration rate dropped dramatically when per capita GDP passed the USD 5,000 mark, but did not actually turn negative (and then only slightly so) until it was on the order of USD 7,500. Taiwan, (1986-92, USD $7,377)$ may be following a similar path. Panama (1980-90, USD 3,162) and Cuba (1970-81, per capita income not available), where reversals of net migration into core regions occurred at surprisingly low levels of development, may be exceptions to the USD 5,000 rule, but neither is a strong counter-example. In Brazil (1980-91, USD 4,080), the rate of net migration into Sao Paolo state has fallen into the low single digits, but it was never particularly high. The dominant role of the oil sector makes it difficult to comment on the cases of Algeria (1977-87, USD 2,669) and Venezuela (1981-91, USD 6,389).

\section{Countries here covered for the first time}

Countries experiencing population concentration. Leaving aside for the moment countries in sub-Saharan Africa, very few of which were covered previously, and the small island nations, most recent observations reveal population concentration in El Salvador (1971-921, per capita income of USD 1,741), Nepal (1971-81, USD 747), Nicaragua (1963-70, USD 1,955), Paraguay (1982-92, USD 2,381), Mongolia (1969-79, per capita income not available), Papua New Guinea (1980-90, USD 1,513) and Morocco (1971-82, USD 1,599). All of these cases conform to the USD 5,000 rule.

Countries experiencing deconcentration. The rate of net migration into the core region is extremely low or negative at levels of per capita income far below USD 5,000 in the following new countries: Costa Rica (1973-84, USD 3,193), Guatemala (1973-81, USD 2,336), Honduras (1974-88, USD 1,303), Jamaica (1982-91, USD 2,358), Myanmar (1973-83, USD 455), Vietnam (197989, per capita income not available) and Iraq (1977-87, USD 4,615). Bolivia presents an odd case, having undergone a significant deconcentration during the most recent inter-censal interval (1976-92, USD 1,741) without ever apparently having passed through the concentration phase.

Bolivia, Costa Rica, Guatemala, Honduras and Jamaica are all small, densely populated countries. Guatemala and Jamaica also have elevated high rates of international out-migration. Vietnam has a rigorous national population redistribution policy aimed at reducing urban population concentration and developing sparsely populated areas. Moreover, constant definitional changes make data interpretation difficult (Banister 1993). The case of Iraq is similarly jejune: both military recruitment and attempts to avoid it may have artificially reduced the population of Baghdad in the 1987 census. This leaves only Myanmar as a new exception to the USD 5,000 rule, and it is not a very compelling one. 
Sub-Saharan Africa and the small island states. Sub-Saharan Africa is of special interest: not only is this region experiencing the most rapid expansion of primate cities, but also it is the focus of the "urban bias" model of concentration. Data problems are acute (so severe, in fact, in the notorious case of Nigeria that we chose not to present data for this country), but, since improvements in census accuracy in Africa are greater for peripheral than for core regions, all of the data presented here tend to underestimate actual concentration trends.

Citing only the most recent observation, the data reveal acutely elevated rates of net migration (in excess of roughly 20 per 1,000 ) into core regions practically across the continent: in Botswana (1981-91, per capita income of USD 2,553), Burkina Faso (1975-85, USD 477), Congo (1974-84, USD 2,099), Ethiopia (1962-70, USD 271), Gambia (1973-83, USD 671), Liberia (1974-84, USD 925), Mauritania (1977-88, USD 987), Sierra Leone (1974-85, USD 974), Tanzania (1978-88, USD 523) and Zimbabwe (1982-92, USD 1,280). "Hypermigration" cannot, by definition, continue for very long. As the cases of Zambia (1980-90, USD 816) and Niger (1977-88, USD 560) illustrate, rates of net migration into the core region can decline not only precipitously, but more importantly, to relatively moderate levels.

In most countries in the African region, the structural adjustment process has led to the collapse of formal urban employment and wages, with consequent disappearance of the much vaunted rural-urban welfare gap (Jamal and Weeks 1988; Robinson 1990). The data presented here, scattered though they are, indicate that migration into African primate cities continues apace despite staggering declines in urban real wages, increases in unemployment, public sector retrenchment and so on. To cite only two examples, Jamal and Weeks report that real urban wages in Sierra Leone dropped by over $80 \%$ between 1970 and 1986, yet, the already elevated rate of net migration into the Western area actually increased between 1963-74 and 1974-85, from 23.3 to 28.2 per 1,000 . In Tanzania, net migration into the Dar es Salaam region proceeded at the brisk rate of 47.2 per 1,000 in 1967-78, a period during which the real minimum wage is estimated to have declined by something like $40 \%$. There has been a further, subsequent drop of over $60 \%$ in the $1980 \mathrm{~s}$, yet the net migration rate was still 18.9 per 1,000 in $1978-88$. In Ghana (1970-84, USD 822) and Côte d'Ivoire (1975-88, USD 1,440), population concentration trends were not particularly extreme even during periods characterized by extreme distortions of the "urban bias" variety. On the face of the matter, then, it appears that "urban bias" is only a contributing factor, not the driving factor behind rapid African urbanization.

Population movements in Sudan (1983-93, USD 1,039) and Uganda (198091, USD 707) are dominated by refugee movements. The apparent deconcentration in Mozambique (1970-80, USD 1,177) is an illusion caused by the combination of improving census accuracy and the civil war. Deconcentration is also observed in Burundi (1979-90, USD 495), Guinea (1977-83, USD 391), and Malawi (1977-87, USD 480). The last of these is a possibly interesting case - it may not be coincidental that Malawi has one of the strongest economic and political decentralization policies in sub-Saharan Africa. 


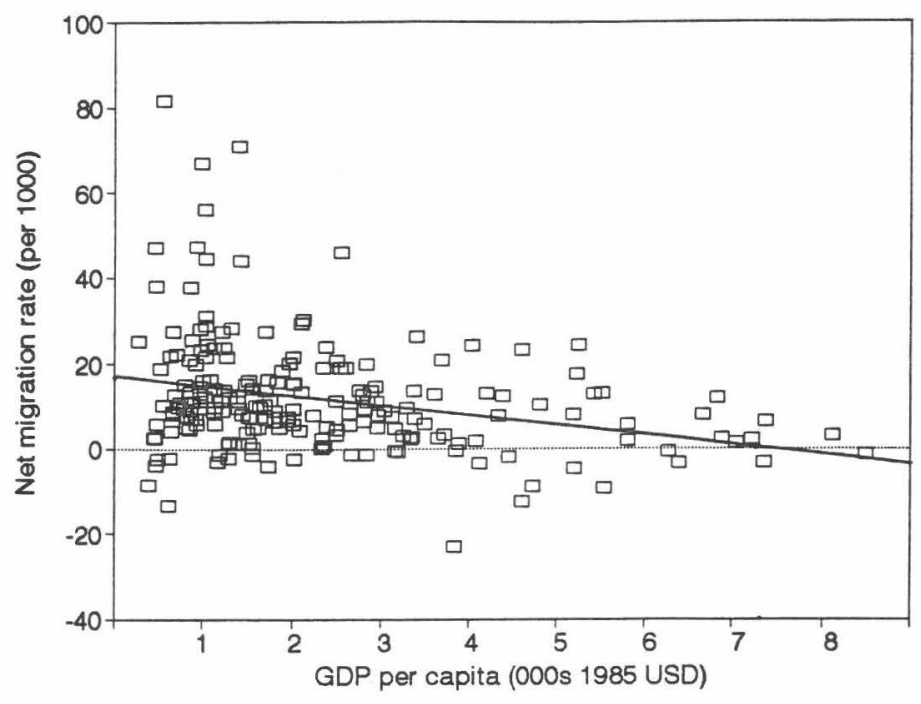

FIGURE 1. Relation Between Net Migration Rate and Per Capita GDP

The small island states present a mixed and not particularly interesting picture. If there is one conclusion that can be elicited, it is that these countries seem to follow no distinctive pattern. Mauritius (1983-90, USD 4,737) is an unusual case, but this is not surprising; it, like Sri Lanka, is a perpetual demographic outlier.

\section{GRAPHICAL SUMMARY}

In Figure 1, we plot the net migration rate into the core region (NMR) against per capita income $(\mathrm{Y})$ and draw the least squares line. The NMR is estimated, as described above, by the difference between the core region and national population growth rates. Income data are the Summers-Heston data referred to previously.

The least squares line is given by:

$$
\begin{aligned}
N M R_{i t}= & 17.43941-0.00238 Y_{i t} \\
& (11.034) \quad(-4.399)
\end{aligned}
$$

with $R^{2}=0.089, N=199$, and $i$ as the index for the country and $t$ for the inter-censal interval. The pronounced outliers in the plot more or less offset each other, so there is little purpose in deleting them. The calculated $x$-intercept of USD 7,327 should not be subjected to too much solemn interpretation in view of the rnediocre fit. On the other hand, riothing in the scatterplot bodes well for the USD 5,000 rule in its naive form. If anything, Figure 1 reinforces a need for caution. The NMR is negatively (albeit weakly) correlated with per capita income; however, it may remain positive after per capita income is well past the USD 5,000 point. 


\section{CONCLUSION}

The experience of DCs in the 1970s and 1980s conformed roughly to predictions of a model that suggested that population redistribution towards core regions would cease at a level of national per capita income of about USD 5,000. Evidence from LDCs through the 1980 round of censuses suggested that the USD 5,000 point was marked only by a slowing of net migration into the core, not by an outright reversal of trend. The body of evidence through the 1990 round of censuses reinforces the need for caution. While there is a weak negative correlation between the rate of net migration into the core region and per capita income, the share of population residing in the core region may continue to rise when per capita income is well beyond USD 5,000 .

\section{ACKNOWLEDGMENT}

Our principal debt is to the librarians of the Center for International Research of the U.S. Bureau of the Census, of the International Labour Office (ILO) in Geneva, of the United Nations Statistical Office in New York and of the African Development Bank in Abidjan, as well as to Zuali Malsawma, Carl Haub and Machiko Yanagishita of the Population Reference Bureau (PRB) in Washington, all for their patience in the face of repeated incursions into their collections. MacKellar's research at the PRB was made possible by the Andrew W. Mellon Foundation through its Mellon Visiting Scholar program. We also thank Andrew Hamer of the World Bank, Richard Anker and Ghazi Faroog of the ILO and three anonymous referees, for their comments on an earlier draft; Samir Radwan of the ILO, for translations from the Arabic; ILO Experts William House and John Herzog, for data and comments from Sudan, Malawi and Zimbabwe; Hassan Yousif of IIASA for comments on Iraq and Judith Banister of the International Research Center of the U.S. Bureau of the Census, for information on Vietnam.

\section{REFERENCES}

Alonso, W. 1971. The economics of urban size. Papers of the Regional Science Association 26: 67-83.

Alperovitch, G. 1992. Economic development and population concentration. Economic Development and Cultural Change 41: 63-74.

Banister, J. 1993. Vietnam population dynamics and prospects. Indochina Research Monograph. Institute of East Asian Studies, University of California at Berkeley.

Bartone, C. 1991. Environmental challenge in Third World cities. Journal of the American Planning Association 57: 411-15.

Boswell, J. 1786. Journal of a journey to the Hebrides with Samuel Johnson, L.L.D. Reprinted 1993. Harmondsworth: Penguin Books.

Champion, A. 1989. Counterurbanization: The changing pace and nature of population concentration. London: Edward Arnold.

Champion, A. 1994. Population change and migration in Britain since 1981: Evidence for continuing deconcentration. Environment and Planning A 26: 1501-20.

Cochrane, S., and Vining, D. 1986. Recent trends in migration between core and peripheral regions in developed and advanced developing countries. Working Papers in Regional Science and Transportation No. 108. Philadelphia: University of Pennsylvania.

Critchfield, R. 1979. Revolution of the village. Human Behavior 8: 18-27.

Critchfield, R. 1981. Villages. New York: Doubleday.

Gilbert, A. 1993. Third World cities: The changing national settlement system. Urban Studies 30: $721-40$.

Gilbert, A. 1994. Third World cities: Poverty, employment, gender roles and the environment during a time of restructuring. Urban Studies 31: 605-33.

Hull, T. 1994. Personal communication regarding the 1990 Indonesian Census.

Izazola, H., and Marquette, C. 1994. Migration in response to urban environmental deterioration: Out-migration by middle-class women and their families from Mexico City since 1985 
Paper presented to the annual meeting of the Population Association of America, Miami, Florida, 5-7 May, 1994.

Jamal, W., and Weeks, J. 1988. The vanishing rural-urban gap in sub-Saharan Africa. International Labour Review 127: 271-92.

Mera, K. 1973. On the urban agglomeration and economic efficiency. Economic Development and Cultural Change 21: 309-24.

Mutlu, S. 1989. Urban concentration and primacy revisited: An analysis and some policy considerations. Economic Development and Cultural Change 37: 611-39.

Parr, J. 1985. A note on the size distribution of cities over time. Journal of Urban Economics 18: 199212.

Petrakos, G. 1992. Urban concentration and agglomeration economies: Re-examining the relationship. Urban Studies 29: 1219-29.

Petrakos, G., and Brada, J. 1989. Metropolitan concentration in developing countries. Kyklos 42: 557-78.

Richardson, H. 1989. The big, bad city: Mega-city myth? Third World Planning Review 11:355-72.

Robinson, D. 1990. Changing civil service remuneration in Africa. International Labour Review 129: 371-86.

Soroka, L. 1994. Manufacturing productivity and city size in Canada, 1975 and 1985: Does population matter? Urban Studies 31: 895-911.

Summers, R., and Heston, A. 1993. The Penn World Table (Mark 5): An expanded set of international comparisons, 1950-1988. Quarterly Journal of Economics 106: 327-68.

Tsuyo, N., and Kuroda, T. 1989. Japan: The slowing of urbanization and metropolitan concentration. NUPRI Reprint Series No, 33. Tokyo: Nihon University Population Research Institute.

United Nations Population Division. 1993. World urbanization prospects: The 1992 revision. New York: United Nations.

Vining, D. 1986. Population redistribution towards core areas of less developed countries, 19501980. International Regional Science Review 10: 1-45.

Vining, D., and Kontuly, T. 1978. Population dispersal from major metropolitan regions: An international comparison. International Regional Science Review 3: 49-73.

Vining, D., and Pallone, R. 1982. Migration between core and peripheral regions: A description and tentative explanation of the patterns in 22 countries. Geoforum 13: 339-410.

Wheaton, W., and Shishido, H. 1981. Urban concentration, agglomeration economies, and the level of econicmic development. Economic Development and Cultural Change 30: 17-30.

World Bank 1986. World development report. Baltimore: Johns Hopkins University Press.

\section{APPENDIX A: POSTWAR POPULATION REDISTRIBUTION}

In Table 1 on the following pages, a highlighted table cell is used to denote new census observations, in the case of countries covered previously by Vining (1986) and to denote countries not covered previously. Unavailable per capita GDP data are indicated by "na" for "not available." A handful of pre-War census observations in Vining (1986) has been dropped.

Every attempt has been made to track down and control for administrative boundary changes; the authors would be grateful to hear from readers who are aware of any changes which they appear to have missed or which have just taken place; ditto new census results as they become available. 
TABLE 1. Postwar Population Redistribution by Country

\begin{tabular}{|c|c|c|c|c|c|c|c|}
\hline $\begin{array}{l}\text { Country and Core Region } \\
\text { Constituent Subdivisions }\end{array}$ & Year & National & usands) & $\begin{array}{l}\text { Share of } \\
\text { Core }(\%)\end{array}$ & $\begin{array}{c}\text { Core - National } \\
\text { Growth Rate } \\
\left(\times 10^{3}\right)\end{array}$ & \multicolumn{2}{|c|}{$\begin{array}{l}\text { GDP per capita (1985 } \\
\text { USD; inter-censal } \\
\text { average) }\end{array}$} \\
\hline \multicolumn{8}{|l|}{ Latin America and Caribbean } \\
\hline Argentina & 1947 & 15,894 & 7,255 & 45.6 & & & \\
\hline \multirow[t]{4}{*}{ Federal Capital; Buenos Aires province } & 1960 & 20,014 & 9,733 & 48.6 & 4.9 & 3,164 & \\
\hline & 1970 & 23,264 & 11,747 & 50.3 & 3.3 & 3,729 & \\
\hline & 1980 & 27,948 & 13,788 & 49.3 & -1.9 & 4,455 & \\
\hline & 1991 & 32,609 & 15,543 & 47.7 & -3.5 & 4,129 & $(80-90)$ \\
\hline Bolivia & 1950 & 3,018 & 948 & 31.4 & & & \\
\hline \multirow[t]{2}{*}{ La Paz department } & 1976 & 4,613 & 1,465 & 31.8 & 0.4 & 1,563 & \\
\hline & 1992 & 6,421 & 1,901 & 29.6 & -4.2 & 1,741 & $(76-90)$ \\
\hline Brazil & 1950 & 51,942 & 9,128 & 17.6 & & & \\
\hline \multirow[t]{4}{*}{ Sao Paolo state } & 1960 & 70,070 & 12,809 & 18.3 & 3.9 & 1,502 & \\
\hline & 1970 & 93,139 & 17,772 & 19.1 & 4.3 & 2,080 & \\
\hline & 1980 & 119,099 & 25,041 & 21.0 & 9.7 & 1,413 & \\
\hline & 1991 & 146,918 & 31,547 & 21.5 & 1.9 & 4,080 & $(80-90)$ \\
\hline Chile & 1952 & 5,933 & 1,755 & 29.6 & & & \\
\hline Santiago province (1952-70); Metropoli- & 1960 & 7,374 & 2,437 & 33.0 & 13.9 & 2,752 & \\
\hline \multirow[t]{3}{*}{$\tan$ Santiago (1982-90) } & 1970 & 8,885 & 3,231 & 36.4 & 9.6 & 3,290 & \\
\hline & 1982 & 11,275 & 4,295 & 38.1 & 5.9 & 3,501 & \\
\hline & 1992 & 13,232 & 5,170 & 39.1 & 2.5 & 3,653 & $(82-90)$ \\
\hline
\end{tabular}


TABLE 1. Postwar Population Redistribution by Country (Continued)

\begin{tabular}{|c|c|c|c|c|c|c|c|}
\hline $\begin{array}{l}\text { Country and Core Region } \\
\text { Constituent Subdivisions }\end{array}$ & Year & National & sands) & $\begin{array}{l}\text { Share of } \\
\text { Core }(\%)\end{array}$ & $\begin{array}{l}\text { Core - National } \\
\text { Growth Rate } \\
\left.\qquad \times 10^{3}\right)\end{array}$ & \multicolumn{2}{|c|}{$\begin{array}{c}\text { GDP per capita (1985 } \\
\text { USD; inter-censal } \\
\text { average) }\end{array}$} \\
\hline Colombia & 1951 & 11,548 & 1,624 & 14.1 & & & \\
\hline Cundinamarca department; Bogota spe- & 1964 & 17,632 & 2,820 & 16.0 & 9.9 & 1,639 & \\
\hline \multirow[t]{3}{*}{ cial district } & 1973 & 22,572 & 4,072 & 18.0 & 13.4 & 2,105 & \\
\hline & 1985 & 27,838 & 5,366 & 19.3 & 5.5 & 2,639 & \\
\hline & 1993 & 35,886 & 8,175 & 22.8 & 9.0 & 3,042 & $(85-90)$ \\
\hline Costa Rica & 1973 & 1,872 & 695 & 37.1 & & & \\
\hline San Juan province & 1984 & 2,419 & 890 & 36.8 & -0.8 & 3,193 & \\
\hline Cuba & 1953 & 5,829 & 1,539 & 26.4 & & & \\
\hline Habana province (1953-70); Habana & 1970 & 8,569 & 2,311 & 27.0 & 1.7 & na & \\
\hline and Ciudad de Habana provinces (1981) & 1981 & 9,724 & 2,515 & 25.9 & -3.8 & na & \\
\hline Dominican Republic & 1950 & 2,136 & 239 & 11.1 & & & \\
\hline \multirow[t]{3}{*}{ National district } & 1960 & 3,047 & 465 & 15.3 & 31.0 & 1,041 & \\
\hline & 1970 & 4,009 & 813 & 20.3 & 28.4 & 1,329 & \\
\hline & 1981 & 5,648 & 1,551 & 27.5 & 27.6 & 1,224 & \\
\hline Ecuador & 1950 & 3,203 & 969 & 30.3 & & & \\
\hline \multirow[t]{4}{*}{ Pinchincha and Guayas provinces } & 1962 & 4,476 & 1,567 & 35.0 & 12.2 & 1,301 & \\
\hline & 1974 & 6,501 & 2,494 & 38.4 & 7.6 & 1,944 & \\
\hline & 1982 & 8,051 & 3,424 & 42.5 & 12.9 & 2,802 & \\
\hline & 1990 & 9,648 & 4,271 & 44.3 & 5.0 & 2,968 & \\
\hline
\end{tabular}


TABLE 1. Postwar Population Redistribution by Country (Continued)

\begin{tabular}{|c|c|c|c|c|c|c|c|}
\hline \multirow{2}{*}{$\begin{array}{l}\text { Country and Core Region } \\
\text { Constituent Subdivisions }\end{array}$} & \multirow{2}{*}{ Year } & \multicolumn{2}{|c|}{ Population (thousands) } & \multirow{2}{*}{$\begin{array}{l}\text { Share of } \\
\text { Core }(\%)\end{array}$} & \multirow{2}{*}{$\begin{array}{l}\text { Core - National } \\
\text { Growth Rate } \\
\qquad\left(\times 10^{3}\right)\end{array}$} & \multirow{2}{*}{\multicolumn{2}{|c|}{$\begin{array}{c}\text { GDP per capita (1985 } \\
\text { USD; inter-censal } \\
\text { average) }\end{array}$}} \\
\hline & & National & Core & & & & \\
\hline El Salvador & 1950 & 1,856 & 296 & 16.0 & & & \\
\hline \multirow[t]{3}{*}{ San Salvador department } & 1961 & 2,511 & 463 & 18.4 & 13.2 & 977 & \\
\hline & 1971 & 3,541 & 731 & 20.6 & 11.3 & 1,206 & \\
\hline & 1992 & 5,048 & 1,478 & 29.3 & 16.6 & 1,741 & $(71-90)$ \\
\hline Guatemala & 1973 & 5,160 & 1,108 & 21.4 & & & \\
\hline Guatemala department & 1981 & 6,054 & 1,311 & 21.7 & 0.5 & 2,336 & \\
\hline Haiti & 1950 & 3,097 & 654 & 21.1 & & & \\
\hline \multirow[t]{2}{*}{ West department } & 1971 & 4,330 & 1,206 & 27.9 & 13.2 & na & \\
\hline & 1982 & 5,054 & 1,552 & 30.7 & 8.9 & 863 & \\
\hline Honduras & 1945 & 1,200 & 174 & 14.5 & & & \\
\hline \multirow{4}{*}{$\begin{array}{l}\text { Françisco Morazon and Cortes depart- } \\
\text { ments }\end{array}$} & 1950 & 1,369 & 316 & 23.1 & 100.0 & na & \\
\hline & 1961 & 1,885 & 484 & 25.7 & 9.7 & 974 & \\
\hline & 1974 & 2,657 & 823 & 31.0 & 14.4 & 1,122 & \\
\hline & 1988 & 4,449 & 1,412 & 31.7 & 1.7 & 1,303 & \\
\hline Jamaica & 1960 & 1,610 & 666 & 41.4 & & & \\
\hline Kingston, St. Andrews, St. Mary and & 1970 & 1,848 & 828 & 44.8 & 8.0 & 2,229 & \\
\hline \multirow[t]{2}{*}{ St. Catherine provinces } & 1982 & 2,190 & 1,023 & 46.7 & 3.5 & 2,487 & \\
\hline & 1991 & 2,366 & 1,113 & 47.0 & 0.8 & 2,358 & $(82-90)$ \\
\hline
\end{tabular}


TABLE 1. Postwar Population Redistribution by Country (Continued)

\begin{tabular}{|c|c|c|c|c|c|c|}
\hline \multirow{2}{*}{$\begin{array}{l}\text { Country and Core Region } \\
\text { Constituent Subdivisions }\end{array}$} & \multirow{2}{*}{ Year } & \multicolumn{2}{|c|}{ Population (thousands) } & \multirow{2}{*}{$\begin{array}{l}\text { Share of } \\
\text { Core }(\%)\end{array}$} & \multirow{2}{*}{$\begin{array}{l}\text { Core - National } \\
\text { Growth Rate } \\
\left.\qquad \times 10^{3}\right)\end{array}$} & \multirow{2}{*}{$\begin{array}{c}\text { GDP per capita (1985 } \\
\text { USD; inter-censal } \\
\text { average) }\end{array}$} \\
\hline & & National & Core & & & \\
\hline Mexico & 1950 & 25,791 & 4,716 & 18.3 & & \\
\hline Mexico and Morales states; Federal Dis- & 1960 & 34,923 & 7,155 & 20.5 & 11.4 & 2,494 \\
\hline \multirow[t]{3}{*}{ trict } & 1970 & 48,225 & 11,323 & 23.5 & 13.6 & 3,380 \\
\hline & 1980 & 66,847 & 17,395 & 26.0 & 10.2 & 4,829 \\
\hline & 1990 & 81,141 & 19,248 & 23.7 & -9.3 & 5,543 \\
\hline Nicaragua & 1950 & 1,050 & 586 & 56.1 & & \\
\hline \multirow[t]{2}{*}{ Pacific region } & 1963 & 1,536 & 870 & 56.6 & 1.1 & 1,405 \\
\hline & 1970 & 1,878 & 1,116 & 59.5 & 6.8 & 1,955 \\
\hline Panama & 1950 & 805 & 248 & 30.8 & & \\
\hline \multirow[t]{4}{*}{ Panama province (excl. Canal Zone) } & 1960 & 1,076 & 372 & 34.6 & 11.5 & 1,394 \\
\hline & 1970 & 1,428 & 577 & 40.4 & 15.6 & 2,009 \\
\hline & 1980 & 1,789 & 829 & 46.3 & 13.7 & 2,894 \\
\hline & 1990 & 2,329 & 1,074 & 46.0 & -0.6 & 3,162 \\
\hline Paraguay & 1972 & 2,358 & 699 & 29.6 & & \\
\hline \multirow[t]{2}{*}{ Asuncion and Central departments } & 1982 & 3,030 & 952 & 31.4 & 5.8 & 2,012 \\
\hline & 1992 & 4,123 & 1,367 & 33.2 & 5.4 & $(82-90)$ \\
\hline
\end{tabular}


TABLE 1. Postwar Population Redistribution by Country (Continued)

\begin{tabular}{|c|c|c|c|c|c|c|c|}
\hline $\begin{array}{l}\text { Country and Core Region } \\
\text { Constituent Subdivisions }\end{array}$ & Year & National & usands) & $\begin{array}{l}\text { Share of } \\
\text { Core }(\%)\end{array}$ & $\begin{array}{c}\text { Core - National } \\
\text { Growth Rate } \\
\left.\qquad \times 10^{3}\right)\end{array}$ & \multicolumn{2}{|c|}{$\begin{array}{c}\text { GDP per capita (1985 } \\
\text { USD; inter-censal } \\
\text { average) }\end{array}$} \\
\hline Peru & 1961 & 9,907 & 2,245 & 22.7 & 20.7 & & \\
\hline Lima department; Callao constitutional & 1972 & $13,5,38$ & 3,794 & 28.0 & 19.3 & 2,355 & \\
\hline \multirow[t]{2}{*}{ province } & 1981 & 17,005 & 5,189 & 30.5 & 9.5 & 2,824 & \\
\hline & 1993 & 22,128 & 7,125 & 32.2 & 4.5 & 2,503 & $(81-90)$ \\
\hline Uruguay & 1963 & 2,596 & 1,461 & 56.3 & 7.1 & & \\
\hline \multirow[t]{2}{*}{ Montevideo and Canelones provinces } & 1975 & 2,788 & 1,563 & 56.0 & -0.4 & 3,857 & \\
\hline & 1985 & 2,931 & 1,663 & 56.7 & 1.2 & 3,898 & \\
\hline Venezuela & 1950 & 5,035 & 1,419 & 28.2 & & & \\
\hline Miranda, Aragua and Carabobo states; & 1961 & 7,524 & 2,445 & 32.5 & 12.9 & 5,436 & \\
\hline \multirow[t]{3}{*}{ Federal District } & 1971 & 10,722 & 3,919 & 36.6 & 11.9 & 6,843 & \\
\hline & 1981 & 14,570 & 5,446 & 37.4 & 2.2 & 7,228 & \\
\hline & 1990 & 19,325 & 7,007 & 36.3 & -3.4 & 6,389 & \\
\hline \multicolumn{8}{|l|}{ East Asia and Pacific } \\
\hline Indonesia & 1961 & 63,060 & 6,705 & 10.6 & & & \\
\hline (Java only) Bogor, Bekasi, Tanggerang & 1971 & 76,086 & 9,200 & 21.1 & 12.9 & 687 & \\
\hline $\begin{array}{l}\text { and Serang Kabupaten; Bogor Kota- } \\
\text { madya; DKI Jakarta }\end{array}$ & 1981 & 91,270 & 13,027 & 14.3 & 16.6 & 1,091 & \\
\hline
\end{tabular}


TABLE 1. Postwar Population Redistribution by Country (Continued)

\begin{tabular}{|c|c|c|c|c|c|c|c|}
\hline $\begin{array}{l}\text { Country and Core Region } \\
\text { Constituent Subdivisions }\end{array}$ & Year & National & usands) & $\begin{array}{l}\text { Share of } \\
\text { Core }(\%)\end{array}$ & $\begin{array}{c}\text { Core - National } \\
\text { Growth Rate } \\
\left.\qquad \times 10^{3}\right)\end{array}$ & \multicolumn{2}{|c|}{$\begin{array}{l}\text { GDP per capita (1985 } \\
\text { USD; inter-censal } \\
\text { average) }\end{array}$} \\
\hline Republic of Korea & 1955 & 21,502 & 3,928 & 18.3 & & & \\
\hline Seoul city; Gyeongi province (1955-80); & 1960 & 24,989 & 5,194 & 20.8 & 25.8 & 894 & \\
\hline Seoul and Inchon cities, Gyeongi prov- & 1966 & 29,193 & 6,911 & 23.7 & 21.7 & 1,037 & \\
\hline \multirow[t]{5}{*}{ ince (1985-90) } & 1970 & 31,435 & 8,879 & 28.2 & 44.1 & 1,427 & \\
\hline & 1975 & 34,707 & 10,929 & 31.5 & 21.7 & 2,013 & \\
\hline & 1980 & 37,449 & 13,202 & 35.5 & 24.1 & 2,371 & \\
\hline & 1985 & 40,448 & 15,828 & 39.1 & 20.9 & 3,695 & \\
\hline & 1990 & 43,520 & 18,586 & 42.7 & 17.5 & 5,238 & $(85-90)$ \\
\hline Malaysia & 1947 & 4,908 & 711 & 14.5 & & & \\
\hline Selangor state; Federal territory (excl. & 1957 & 6,279 & 1,013 & 16.1 & 10.8 & na & \\
\hline \multirow[t]{3}{*}{ Sarawak) } & 1970 & 8,810 & 1,630 & 18.5 & 10.5 & 1,695 & \\
\hline & 1980 & 10,945 & 2,346 & 21.4 & 14.7 & 2,945 & \\
\hline & 1990 & 14,182 & 3,489 & 24.6 & 12.5 & 4,338 & $(80-90)$ \\
\hline Mongolia & 1963 & 10,171 & 2,237 & 22.0 & & & \\
\hline \multirow[t]{2}{*}{ Ulan Bator ä̈mak } & 1969 & 11,976 & 2,674 & 22.3 & 2.5 & na & \\
\hline & 1979 & 15,950 & 4,023 & 25.2 & 12.2 & na & \\
\hline Myanmar & 1973 & 28,085 & 6,856 & 24.4 & & & \\
\hline Yangon and Mandalay divisions & 1983 & 34,125 & 8,544 & 25.0 & 2.5 & 455 & \\
\hline
\end{tabular}


TABLE 1. Postwar Population Redistribution by Country (Continued)

\begin{tabular}{|c|c|c|c|c|c|c|c|}
\hline \multirow{2}{*}{$\begin{array}{l}\text { Country and Core Region } \\
\text { Constituent Subdivisions }\end{array}$} & \multirow{2}{*}{ Year } & \multicolumn{2}{|c|}{ Population (thousands) } & \multirow{2}{*}{$\begin{array}{l}\text { Share of } \\
\text { Core }(\%)\end{array}$} & \multirow{2}{*}{$\begin{array}{l}\text { Core - National } \\
\text { Growth Rate } \\
\qquad\left(\times 10^{3}\right)\end{array}$} & \multirow{2}{*}{\multicolumn{2}{|c|}{$\begin{array}{c}\text { GDP per capita (1985 } \\
\text { USD; inter-censal } \\
\text { average) }\end{array}$}} \\
\hline & & National & Core & & & & \\
\hline 'Papua New Guinea & 1966 & 2,150 & 135 & 6.3 & & & \\
\hline \multirow[t]{3}{*}{ Central province; National Capital District } & 1971 & 2,342 & 169 & 7.2 & 27.8 & 1,703 & \\
\hline & 1980 & 2,978 & 229 & 7.7 & 7.1 & 1,697 & \\
\hline & 1990 & 3,689 & 334 & 9.0 & 16.3 & 1,513 & \\
\hline Philippines & 1948 & 19,234 & 2,745 & 14.3 & & & \\
\hline Bataan, Bulacan, Cavite, Laguna and & 1960 & 27,088 & 4,147 & 15.3 & 5.8 & 942 & $(50-60)$ \\
\hline \multirow[t]{4}{*}{ Rizal provinces; Metropolitan Manila } & 1970 & 36,684 & 6,449 & 17.6 & 13.8 & 1,244 & \\
\hline & 1975 & 42,071 & 7,981 & 19.0 & 15.2 & 1,496 & \\
\hline & 1980 & 47,914 & 9,639 & 20.1 & 11.7 & 1,746 & \\
\hline & 1990 & 60,477 & 13,263 & 21.9 & 9.0 & 1,810 & \\
\hline Taiwan & 1956 & 9,311 & 1,818 & 19.5 & & & \\
\hline Taipei and Taoyuan hsien; Taiwan & 1966 & 13,348 & 3,007 & 22.5 & 14.3 & 1,560 & \\
\hline \multirow[t]{5}{*}{ municipality; Keelung city } & 1970 & 14,693 & 3,736 & 25.4 & 30.3 & 2,132 & \\
\hline & 1975 & 16,206 & 4,554 & 28.1 & 20.0 & 2,829 & \\
\hline & 1980 & 17,969 & 5,700 & 31.7 & 24.2 & 4,049 & \\
\hline & 1986 & 19,454 & 6,884 & 35.4 & 13.2 & 5,535 & \\
\hline & 1992 & 20,656 & 7,599 & 36.9 & 6.5 & 7,377 & $(86-90)$ \\
\hline
\end{tabular}


TABLE 1. Postwar Population Redistribution by Country (Continued)

\begin{tabular}{|c|c|c|c|c|c|c|c|}
\hline $\begin{array}{l}\text { Country and Core Region } \\
\text { Constituent Subdivisions }\end{array}$ & Year & National & usands) & $\begin{array}{l}\text { Share of } \\
\text { Core }(\%)\end{array}$ & $\begin{array}{c}\text { Core - National } \\
\text { Growth Rate } \\
\left.\qquad \times 10^{3}\right)\end{array}$ & \multicolumn{2}{|c|}{$\begin{array}{c}\text { GDP per capita (1985 } \\
\text { USD; inter-censal } \\
\text { average) }\end{array}$} \\
\hline 'Thailand & 1947 & 17,433 & 1,476 & 8.5 & & & \\
\hline Phra Nakhon, Thon Buri, Nonthanburi & 1960 & 26,258 & 2,567 & 9.8 & 11.1 & 888 & $(50-60)$ \\
\hline and Prakan changwats (1947-70); & 1970 & 34,397 & $3,67 \mathrm{~s}$ & 10.7 & 8.9 & 1,219 & \\
\hline Bangkok and Samat Prakan changwats & 1980 & 44,278 & 5,547 & 12.5 & 15.9 & 1,827 & \\
\hline$(1980-90)$ & 1992 & 57,789 & 7,133 & 12.3 & -1.2 & 2,839 & $(80-90)$ \\
\hline Vietnam & 1979 & 52,742 & 7,270 & 13.8 & & & \\
\hline Ho Chi Minh, Haiphong and Hanoi cities & 1989 & 64,376 & 8,428 & 13.1 & -5.2 & na & \\
\hline \multicolumn{8}{|l|}{ South Asia } \\
\hline Bangladesh & 1951 & 41,932 & 4,073 & 9.7 & & & \\
\hline \multirow[t]{4}{*}{ Dhaka district } & 1961 & 50,840 & 5,096 & 10.0 & 3.1 & na & \\
\hline & 1974 & 71,479 & 7,612 & 10.6 & 4.7 & 853 & \\
\hline & 1981 & 87,120 & 10,014 & 11.5 & 10.9 & 966 & \\
\hline & 1991 & 104,766 & 13,151 & 12.5 & 8.8 & 1,122 & $(81-90)$ \\
\hline India & 1961 & 424,836 & 12,246 & 2.9 & & & \\
\hline \multirow[t]{3}{*}{ Calcutta, Greater Bombay } & 1971 & 528,918 & 16,647 & 3.1 & 8.8 & 671 & \\
\hline & 1981 & 658,141 & 23,107 & 3.5 & 10.9 & 747 & \\
\hline & 1991 & 843,931 & 31,805 & 3.8 & 7.1 & 929 & $(81-90)$ \\
\hline Nepal & 1981 & 15,023 & 422 & 2.8 & & & \\
\hline Kathmandu district & 1991 & 18,491 & 675 & 3.6 & 38.0 & 868 & $(81-86)$ \\
\hline
\end{tabular}


TABLE 1. Postwar Population Redistribution by Country (Continued)

\begin{tabular}{|c|c|c|c|c|c|c|c|}
\hline \multirow{3}{*}{ Constituent Subdivisions } & \multirow{3}{*}{$\begin{array}{c}\text { Year } \\
1961\end{array}$} & \multicolumn{2}{|c|}{ Population (thousands) } & \multirow{3}{*}{$\begin{array}{c}\text { Share of } \\
\text { Core }(\%)\end{array}$} & \multirow{3}{*}{$\begin{array}{l}\text { Core - National } \\
\text { Growth Rate } \\
\qquad\left(\times 10^{3}\right)\end{array}$} & \multirow{2}{*}{\multicolumn{2}{|c|}{$\begin{array}{l}\text { GDP per capita (1985 } \\
\text { USD; inter-censal } \\
\text { average) }\end{array}$}} \\
\hline & & National & Core & & & & \\
\hline & & 42,880 & 2,135 & & & & \\
\hline \multirow[t]{2}{*}{ Karachi division } & 1971 & 65,309 & 3,607 & 5.5 & 9.4 & 790 & \\
\hline & 1981 & 83,782 & 5,353 & 6.4 & 16.2 & 1,006 & \\
\hline Sri Lanka & 1946 & 6,657 & 1,420 & 5.0 & & & \\
\hline Colombo district (1946-71); Colombo & 1953 & 8,098 & 1,709 & 21.1 & -1.5 & na & \\
\hline \multirow[t]{4}{*}{ and Gampaha districts (1981-91) } & 1963 & 10,582 & 2,207 & 20.9 & -1.2 & 1,194 & \\
\hline & 1971 & 12,690 & 2,672 & 21.1 & 1.2 & 1,286 & \\
\hline & 1981 & 14,850 & 3,088 & 20.8 & -1.2 & 1,565 & \\
\hline & 1991 & 17,261 & 3,500 & 20.3 & -2.5 & 2,018 & $(81-89)$ \\
\hline \multicolumn{8}{|l|}{ North Africa and Middle East } \\
\hline Algeria & 1954 & 9,530 & 1,110 & 11.6 & & & \\
\hline \multirow[t]{3}{*}{ Alger and Bleda wilayate } & 1966 & 12,102 & 1,648 & 13.6 & 13.0 & na & \\
\hline & 1977 & 15,645 & 2,519 & 16.1 & 15.2 & 2,022 & \\
\hline & 1987 & 23,039 & 3,663 & 15.9 & -1.3 & 2,669 & \\
\hline Egypt & 1947 & 18,976 & 3,639 & 19.2 & & & \\
\hline \multirow[t]{4}{*}{ Cairo, Giza and Kalyubia governates } & 1960 & 25,984 & 5,674 & 21.8 & 10.0 & 739 & $(50-60)$ \\
\hline & 1966 & 29,942 & 7,082 & 23.7 & 13.3 & 869 & \\
\hline & 1976 & 36,626 & 9,172 & 25.0 & 5.7 & 1,133 & \\
\hline & 1986 & 48,205 & 12,267 & 25.4 & 4.8 & 1,568 & \\
\hline
\end{tabular}


TABLE 1. Postwar Population Redistribution by Country (Continued)

\begin{tabular}{|c|c|c|c|c|c|c|}
\hline \multirow{2}{*}{$\begin{array}{l}\text { Country and Core Region } \\
\text { Constituent Subdivisions }\end{array}$} & \multirow{2}{*}{ Year } & \multicolumn{2}{|c|}{ Population (thousands) } & \multirow{2}{*}{$\begin{array}{l}\text { Share of } \\
\text { Core }(\%)\end{array}$} & \multirow{2}{*}{$\begin{array}{l}\text { Core - National } \\
\text { Growth Rate } \\
\qquad\left(\times 10^{3}\right)\end{array}$} & \multirow{2}{*}{$\begin{array}{l}\text { GDP per capita (1985 } \\
\text { USD; inter-censal } \\
\text { average) }\end{array}$} \\
\hline & & National & Core & & & \\
\hline Iraq & 1965 & 8,047 & 1,597 & 19.8 & & \\
\hline \multirow[t]{2}{*}{ Baghdad City governate } & 1977 & 12,000 & $3,19 \mathrm{c}$ & 26.6 & 24.4 & 5,256 \\
\hline & 1987 & 16,335 & 3,841 & 23.5 & -12.3 & 4,615 \\
\hline Israel & 1948 & 717 & 556 & 77.5 & & \\
\hline Haifa, Central and Tel Aviv districts & 1961 & 1,932 & 1,395 & 72.2 & -5.5 & na \\
\hline \multirow[t]{2}{*}{ (excl. Arab population) } & 1972 & 2,687 & $1,844^{\circ}$ & 68.6 & -4.6 & 5,218 \\
\hline & 1983 & 3,350 & 2,219 & 66.2 & -3.2 & 7,358 \\
\hline Jordan & 1961 & 901 & 434 & 48.2 & & \\
\hline Amman governate (excl. West Bank) & 1979 & 2,152 & 1,188 & 55.2 & 7.6 & 1,861 \\
\hline Morocco & 1960 & 11,626 & 1,562 & 13.0 & & \\
\hline Casablanca and Rabat-Sale prefectures; & 1971 & 15,379 & 2,704 & 17.6 & 24.5 & 1,056 \\
\hline Ben Slimane province; Kenitra district & 1982 & 20,265 & 3,982 & 19.7 & 10.1 & 1,599 \\
\hline Syria & 1960 & 4,565 & 1,003 & 22.0 & & \\
\hline \multirow[t]{2}{*}{ Damascus city; Damascus mohafazat } & 1970 & 6,305 & 1,458 & 23.1 & 5.1 & 1,860 \\
\hline & 1981 & 9,172 & 2,170 & 23.7 & 2.1 & 3,338 \\
\hline Tunisia & 1966 & 4,533 & 1,443 & 31.8 & & \\
\hline Tunis district; Nabeul, Zaghoun and & 1975 & 5,588 & 1,861 & 33.3 & 5.0 & 1,616 \\
\hline Birzete governates & 1984 & 6,966 & 2,370 & 34.0 & 2.4 & 2,334 \\
\hline
\end{tabular}


TABLE 1. Postwar Population Redistribution by Country (Continued)

\begin{tabular}{|c|c|c|c|c|c|c|c|}
\hline \multirow{2}{*}{$\begin{array}{l}\text { Country and Core Region } \\
\text { Constituent Subdivisions }\end{array}$} & \multirow{2}{*}{ Year } & \multicolumn{2}{|c|}{ Population (thousands) } & \multirow{2}{*}{$\begin{array}{l}\text { Share of } \\
\text { Core }(\%)\end{array}$} & \multirow{2}{*}{$\begin{array}{c}\text { Core - National } \\
\text { Growth Rate } \\
\left.\qquad \times 10^{3}\right)\end{array}$} & \multirow{2}{*}{\multicolumn{2}{|c|}{$\begin{array}{c}\text { GDP per capita (1985 } \\
\text { USD; inter-censal } \\
\text { average) }\end{array}$}} \\
\hline & & National & Core & & & & \\
\hline \multicolumn{8}{|l|}{ Sub-Saharan Africa } \\
\hline Botswana & 1971 & 574 & 18 & 3.1 & & & \\
\hline \multirow[t]{2}{*}{ Gaborene district } & 1981 & 941 & 60 & 6.4 & 71.0 & 1,406 & \\
\hline & 1991 & 1,327 & $13 t^{2}$ & 10.1 & 46.1 & 2,553 & $(81-89)$ \\
\hline Burkina Faso & 1975 & 5,638 & 503 & 8.9 & & & \\
\hline Kadiogo and Horiet provinces & 1985 & 7,965 & 1,041 & 13.1 & 38.2 & 477 & \\
\hline Burundi & 1979 & 4,029 & 460 & 11.4 & & & \\
\hline $\begin{array}{l}\text { Bujumbura-ville and Bujumbura-rural } \\
\text { provinces }\end{array}$ & 1990 & 5,365 & 596 & 11.1 & -2.5 & 495 & \\
\hline Congo & 1974 & 1,320 & 302 & 22.9 & & & \\
\hline Brazaville commune & 1984 & 1,909 & 585 & 30.6 & 29.4 & 2,099 & \\
\hline Côte d'Ivoire & 1975 & 6,703 & 1,389 & 20.6 & & & \\
\hline Abidjan department & 1988 & 10,813 & 2,492 & 23.1 & 8.2 & 1,440 & $(78-90)$ \\
\hline Ethiopia & 1962 & 20,380 & 4,060 & 19.9 & & & \\
\hline Shoa regionve & 1970 & 20,487 & 4,993 & 24.4 & 25.2 & 271 & \\
\hline Gambia & 1973 & 493 & 79 & 16.0 & & & \\
\hline $\begin{array}{l}\text { Banjul and Kombo St. Mary administra- } \\
\text { tive divisions }\end{array}$ & 1983 & 696 & 147 & 21.1 & 27.6 & 671 & \\
\hline
\end{tabular}


TABLE 1. Postwar Population Redistribution by Country (Continued)

\begin{tabular}{|c|c|c|c|c|c|c|}
\hline \multirow{2}{*}{$\begin{array}{l}\text { Country and Core Region } \\
\text { Constituent Subdivisions }\end{array}$} & \multirow{2}{*}{ Year } & \multicolumn{2}{|c|}{ l'opulation (thousands) } & \multirow{2}{*}{$\begin{array}{l}\text { Share of } \\
\text { Core }(\%)\end{array}$} & \multirow{2}{*}{$\begin{array}{l}\text { Core - National } \\
\text { Growth Rate } \\
\left.\qquad \times 10^{3}\right)\end{array}$} & \multirow{2}{*}{$\begin{array}{c}\text { GDP per capita (1985 } \\
\text { USD; inter-censal } \\
\text { average) }\end{array}$} \\
\hline & & National & Core & & & \\
\hline Ghana & 1970 & 8,559 & 903 & 10.5 & & \\
\hline Greater Accra region & 1984 & 12,296 & 1,431 & 11.6 & 7.0 & 882 \\
\hline Guinea & 1977 & 4,527 & 578 & 12.8 & & \\
\hline Conakry region & 1983 & 5,781 & 705 & 12.2 & -8.5 & 391 \\
\hline Guinea-Bissau & 1950 & 517 & 18 & 3.5 & & \\
\hline Bissau autonomous region & 1979 & 777 & 109 & 14.0 & 48.1 & na \\
\hline Kenya & 1962 & 8,634 & 344 & 4.0 & & \\
\hline \multirow[t]{2}{*}{ Nairobi area } & 1969 & 10,957 & 509 & 4.6 & 21.9 & 638 \\
\hline & 1979 & 15,327 & 828 & 5.4 & 15.1 & 802 \\
\hline Lesotho & 1966 & 969 & 202 & 20.8 & & \\
\hline Maseru district (incl. migrant workers & 1976 & 1,217 & 222 & 18.3 & -13.3 & 614 \\
\hline temporarily residing in South Africa) & 1986 & 1,578 & 311 & 19.7 & 7.7 & 818 \\
\hline Liberia & 1962 & 1,016 & 169 & 16.6 & & \\
\hline \multirow[t]{2}{*}{ Montserrado county } & 1974 & 1,503 & 322 & 21.4 & 21.1 & 855 \\
\hline & 1984 & 2,102 & 549 & 25.9 & 19.8 & 925 \\
\hline Madagascar & 1966 & 6,200 & 1,580 & 25.5 & & \\
\hline Tananarive province & 1975 & 7,604 & 2,168 & 28.5 & 12.5 & 1,035 \\
\hline
\end{tabular}


TABLE 1. Postwar Population Redistribution by Country (Continued)

\begin{tabular}{|c|c|c|c|c|c|c|c|}
\hline \multirow{2}{*}{$\begin{array}{l}\text { Country and Core Region } \\
\text { Constituent Subdivisions }\end{array}$} & \multirow{2}{*}{ Year } & \multicolumn{2}{|c|}{ Population (thousands) } & \multirow{2}{*}{$\begin{array}{l}\text { Share of } \\
\text { Core }(\%)\end{array}$} & \multirow{2}{*}{$\begin{array}{l}\text { Core - National } \\
\text { Growth Rate } \\
\qquad\left(\times 10^{3}\right)\end{array}$} & \multirow{2}{*}{\multicolumn{2}{|c|}{$\begin{array}{l}\text { GDP per capita (1985 } \\
\text { USD; inter-censal } \\
\text { average) }\end{array}$}} \\
\hline & & National & Core & & & & \\
\hline 'Malawi & 1966 & 4,040 & 498 & 12.3 & & & \\
\hline \multirow[t]{2}{*}{ Lilongwe district } & 1977 & 5,547 & 704 & 12.7 & 2.7 & 460 & \\
\hline & 1987 & 7,988 & 976 & 12.2 & -3.8 & 480 & \\
\hline Mali & 1976 & 6,395 & 1,351 & 21.1 & & & \\
\hline Bamako district; Koulikoro region & 1985 & 7,838 & 1,745 & 22.3 & 5.8 & 487 & \\
\hline Mauritania & 1965 & 1,098 & 78 & 7.1 & & & \\
\hline \multirow[t]{2}{*}{ Nouakchott district } & 1977 & 1,339 & 135 & 10.1 & 29.2 & 1,048 & \\
\hline & 1988 & 1,864 & 393 & 21.1 & 67.1 & 987 & \\
\hline Mozambique & 1960 & 6,604 & 3,528 & 53.4 & & & \\
\hline Maputo city; Maputo, Nampula and & 1970 & 8,169 & 4,264 & 52.2 & -2.3 & 1,294 & \\
\hline Zambezi provinces & 1980 & 11,674 & 5,901 & 50.5 & -2.9 & 1,177 & \\
\hline Namibia & 1970 & 737 & 436 & 59.2 & & & \\
\hline Owambo, Kavango and Windhoek dis- & 1981 & 1,033 & 668 & 64.6 & 8.1 & 2,975 & \\
\hline tricts & 1991 & 1,402 & 910 & 64.9 & 0.3 & 2,323 & $(81-90)$ \\
\hline Niger & 1960 & 2,980 & 34 & 1.1 & & & \\
\hline \multirow[t]{2}{*}{ Niger city } & 1977 & 5,104 & 233 & 4.6 & 81.6 & & \\
\hline & 1988 & 7,222 & 392 & 5.4 & 10.2 & 560 & \\
\hline
\end{tabular}


TABLE 1. Postwar Population Redistribution by Country (Continued)

\begin{tabular}{|c|c|c|c|c|c|c|c|}
\hline $\begin{array}{l}\text { Country and Core Region } \\
\text { Constituent Subdivisions }\end{array}$ & Year & \multicolumn{2}{|c|}{ Population (thousands) } & $\begin{array}{l}\text { Share of } \\
\text { Core }(\%)\end{array}$ & $\begin{array}{l}\text { Core - National } \\
\text { Growth Rate } \\
\left.\qquad \times 10^{3}\right)\end{array}$ & \multicolumn{2}{|c|}{$\begin{array}{c}\text { GDP per capita (1985 } \\
\text { USD; inter-censal } \\
\text { average) }\end{array}$} \\
\hline Rwanda & 1978 & 4,832 & 698 & 14.4 & & & \\
\hline $\begin{array}{l}\text { Kigali prefecture (1978); Kigali prefecture } \\
\text { and Kigali city (1991) }\end{array}$ & 1991 & 7,149 & 1,151 & 16.1 & 8.3 & 663 & $(78-90)$ \\
\hline Sierra Leone & 1948 & 1,858 & 125 & 6.7 & & & \\
\hline \multirow[t]{3}{*}{ Western area } & 1963 & 2.180 & 195 & 8.9 & 19.0 & na & \\
\hline & 1974 & 2,735 & 316 & 11.6 & 23.3 & 981 & \\
\hline & 1985 & 3,516 & 554 & 15.8 & 28.2 & 974 & \\
\hline Sudan & $1955 / 56$ & 10,263 & 246 & 2.4 & & & \\
\hline \multirow[t]{3}{*}{ Khartoum state } & 1973 & 14,819 & 738 & 5.0 & 40.6 & na & \\
\hline & 1983 & 21,593 & 1,344 & 6.2 & 56.4 & 1,030 & \\
\hline & 1993 & 24,941 & 3,413 & 13.7 & 44.7 & 1,039 & $(83-90)$ \\
\hline Tanzania & 1967 & 12,313 & 356 & 2.9 & & & \\
\hline \multirow[t]{2}{*}{ Dar es Salaam region } & 1978 & 17,528 & 852 & 4.9 & 47.2 & 471 & \\
\hline & 1988 & 23,174 & 1,361 & 5.9 & 18.9 & 523 & \\
\hline Uganda & 1969 & 9,535 & 331 & 3.5 & & & \\
\hline \multirow[t]{2}{*}{ Kampala district } & 1980 & 12,636 & 459 & 3.6 & 4.1 & 651 & \\
\hline & 1991 & 16,672 & 774 & 4.6 & 22.3 & 707 & $(80-90)$ \\
\hline
\end{tabular}


TABLE 1. Postwar Population Redistribution by Country (Continued)

\begin{tabular}{|c|c|c|c|c|c|c|c|}
\hline \multirow{2}{*}{$\begin{array}{l}\text { Country and Core Region } \\
\text { Constituent Subdivisions }\end{array}$} & \multirow{2}{*}{ Year } & \multicolumn{2}{|c|}{ Population (thousands) } & \multirow{2}{*}{$\begin{array}{l}\text { Share of } \\
\text { Core }(\%)\end{array}$} & \multirow{2}{*}{$\begin{array}{l}\text { Core - National } \\
\text { Growth Rate } \\
\left.\qquad \times 10^{3}\right)\end{array}$} & \multirow{2}{*}{\multicolumn{2}{|c|}{$\begin{array}{c}\text { GDP per capita (1985 } \\
\text { USD; inter-censal } \\
\text { average) }\end{array}$}} \\
\hline & & National & Core & & & & \\
\hline Zambia & 1963 & 3,490 & 739 & 21.2 & & & \\
\hline \multirow[t]{3}{*}{ Copperbelt and Lusaka provinces } & 1969 & 4,057 & 1,170 & 28.8 & 47.4 & 938 & \\
\hline & 1980 & 5,675 & 1,925 & 33.9 & 14.7 & 973 & \\
\hline & 1990 & 7,818 & 2,787 & 35.6 & 5.0 & 816 & \\
\hline Zimbabwe & 1969 & 5,099 & 880 & 17.2 & & & \\
\hline Mashonaland East (1969); Mashonaland & 1982 & 7,608 & 1,496 & 19.7 & 10.0 & 1,140 & \\
\hline East and Harare provinces $(1982,1992)$ & 1992 & 10,402 & 2,512 & 24.1 & 21.7 & 1,280 & $(82-90)$ \\
\hline \multicolumn{8}{|l|}{ Europe } \\
\hline Greece & 1951 & 7,633 & 1,556 & 20.4 & & & \\
\hline Greater Athens region; Attica depart- & 1961 & 8,389 & 2,058 & 24.5 & 18.5 & 1,894 & \\
\hline \multirow[t]{3}{*}{ ment } & 1971 & 8,769 & 2,798 & 31.9 & 26.3 & 3,414 & \\
\hline & 1981 & 9,740 & 3,369 & 34.6 & 8.1 & 5,197 & \\
\hline & 1991 & 10,264 & 3,523 & 34.3 & -0.8 & 6,278 & $(81-90)$ \\
\hline Ireland & 1951 & 2,961 & 888 & 30.0 & & & \\
\hline Dublin, Kildare, Meath and Micklow & 1956 & 2,898 & 898 & 31.0 & 6.5 & 2,805 & \\
\hline \multirow[t]{3}{*}{ counties; Dublin county borough } & 1961 & 2,818 & 906 & 32.2 & 7.4 & 3,122 & \\
\hline & 1966 & 2,884 & 989 & 34.3 & 12.9 & 3,605 & \\
\hline & 1971 & 2,978 & 1,062 & 35.7 & 7.8 & 4,342 & \\
\hline
\end{tabular}


TABLE 1. Postwar Population Redistribution by Country (Continued)

\begin{tabular}{|c|c|c|c|c|c|c|c|}
\hline \multirow{2}{*}{$\begin{array}{l}\text { Country and Core Region } \\
\text { Constituent Subdivisions }\end{array}$} & \multirow{2}{*}{ Year } & \multicolumn{2}{|c|}{ Population (thousands) } & \multirow{2}{*}{$\begin{array}{l}\text { Share of } \\
\text { Core (\%) }\end{array}$} & \multirow{2}{*}{$\begin{array}{l}\text { Core - National } \\
\text { Growth Rate } \\
\left(\times 10^{3}\right)\end{array}$} & \multirow{2}{*}{\multicolumn{2}{|c|}{$\begin{array}{c}\text { GDP per capita (1985 } \\
\text { USD; inter-censal } \\
\text { average) }\end{array}$}} \\
\hline & & National & Core & & & & \\
\hline \multirow[t]{4}{*}{ Ireland (Continued) } & 1979 & 3,368 & 1,256 & 37.3 & 5.6 & 5,814 & \\
\hline & 1981 & 3,440 & 1,289 & 37.5 & 2.4 & 6,885 & \\
\hline & 1986 & 3,541 & 1,336 & 37.7 & 1.4 & 7,054 & \\
\hline & 1991 & 3,523 & 1,350 & 38.3 & 3.1 & 8,112 & $(86-90)$ \\
\hline Portugal & 1950 & 8,441 & 1,551 & 18.4 & & & \\
\hline \multirow[t]{4}{*}{ Lisboa, Setubal districts } & 1960 & 8,889 & 1,760 & 19.8 & 7.5 & 1,540 & \\
\hline & 1970 & 8,668 & 2,076 & 24.0 & 19.1 & 2,596 & \\
\hline & 1981 & 9,803 & 2,711 & 27.7 & 13.1 & 4,208 & \\
\hline & 1990 & 9,853 & 2,778 & 28.2 & 1.9 & 5,809 & $(81-90)$ \\
\hline Spain & 1950 & 27,977 & 4,158 & 14.9 & & & \\
\hline \multirow[t]{4}{*}{ Barcelona, Madrid provinces } & 1960 & 30,431 & 5,484 & 18.0 & 19.3 & 2,535 & \\
\hline & 1970 & 34,003 & 7,722 & 22.7 & 23.0 & 4,607 & \\
\hline & 1981 & 37,746 & 9,346 & 24.8 & 7.9 & 6,668 & \\
\hline & 1990 & 38,999 & 9,541 & 24.4 & -1.3 & 8,492 & \\
\hline Turkey & 1950 & 20,947 & 2,755 & 13.2 & & & \\
\hline \multirow[t]{2}{*}{ Istanbul, Ankara and Izmir provinces } & 1955 & 24,065 & 3,565 & 14.8 & 23.8 & 1,242 & \\
\hline & 1960 & 27,755 & 4,267 & 15.4 & 7.4 & 1,517 & \\
\hline
\end{tabular}


TABLE 1. Postwar Population Redistribution by Country (Continued)

\begin{tabular}{|c|c|c|c|c|c|c|c|}
\hline $\begin{array}{l}\text { Country and Core Region } \\
\text { Constituent Subdivisions }\end{array}$ & Year & Populatio & Population (thousands) & $\begin{array}{l}\text { Share of } \\
\text { Core }(\%)\end{array}$ & $\begin{array}{l}\text { Core - National } \\
\text { Growth Rate } \\
\qquad\left(\times 10^{3}\right)\end{array}$ & \multicolumn{2}{|c|}{$\begin{array}{l}\text { GDP per capita (1985 } \\
\text { USD; inter-censal } \\
\text { average) }\end{array}$} \\
\hline \multirow{6}{*}{ Turkey (Continued) } & 1965 & 31,391 & 5,173 & 16.5 & 13.9 & 1,699 & \\
\hline & 1970 & 35,605 & 6,488 & 18.2 & 20.1 & 1,968 & \\
\hline & 1975 & 40,348 & 8,164 & 20.2 & 20.9 & 2,506 & \\
\hline & 1980 & 44,737 & 9,573 & 21.4 & 11.2 & 2,843 & \\
\hline & 1985 & 50,664 & 11,466 & 22.6 & 11.2 & 2,956 & \\
\hline & 1990 & 56,473 & 13,241 & 23.4 & 7.1 & 3,385 & \\
\hline \multicolumn{8}{|l|}{ Small Island States } \\
\hline Bahrain & 1959 & 143 & 62 & 43.3 & & & \\
\hline \multirow[t]{3}{*}{ Manama division } & 1965 & 182 & 79 & 43.4 & 0.2 & na & \\
\hline & 1971 & 216 & 89 & 41.2 & -8.7 & na & \\
\hline & 1981 & 350 & 122 & 34.9 & 16.7 & na & \\
\hline Cape Verde & 1980 & 289 & 56 & 19.4 & & & \\
\hline Praia county & 1990 & 337 & 83 & 24.6 & 23.7 & 1,129 & $(80-89)$ \\
\hline Comoros & 1966 & 212 & 62 & 29.2 & & & \\
\hline $\begin{array}{l}\text { (excl. Mayotte) Grand Comore Island; } \\
\text { Centre prefecture }\end{array}$ & 1980 & 335 & 95 & 28.4 & -2.2 & 627 & \\
\hline Cyprus & 1946 & 450 & 145 & 32.4 & & & \\
\hline \multirow[t]{2}{*}{ Nicosia district } & 1960 & 574 & 204 & 35.6 & 6.5 & 1,807 & $(50-60)$ \\
\hline & 1973 & 632 & 233 & 36.8 & 2.6 & 3,363 & \\
\hline
\end{tabular}


TABLE 1. Postwar Population Redistribution by Country (Continued)

\begin{tabular}{|c|c|c|c|c|c|c|}
\hline \multirow{2}{*}{$\begin{array}{l}\text { Country and Core Region } \\
\text { Constituent Subdivisions }\end{array}$} & \multirow{2}{*}{ Year } & \multicolumn{2}{|c|}{ Population (thousands) } & \multirow{2}{*}{$\begin{array}{l}\text { Share of } \\
\text { Core }(\%)\end{array}$} & \multirow{2}{*}{$\begin{array}{l}\text { Core - National } \\
\text { Growth Rate } \\
\left.\qquad \times 10^{3}\right)\end{array}$} & \multirow{2}{*}{$\begin{array}{c}\text { GDP per capita (1985 } \\
\text { USD; inter-censal } \\
\text { average) }\end{array}$} \\
\hline & & National & Core & & & \\
\hline Fiji & 1966 & 476 & 154 & 32.3 & & \\
\hline \multirow[t]{2}{*}{ Central division } & 1976 & 588 & 207 & 35.2 & 8.4 & 2,645 \\
\hline & 1986 & 715 & 260 & 36.4 & 3.2 & 3,263 \\
\hline Kiribati & 1947 & 28 & 4 & 12.9 & & \\
\hline \multirow[t]{5}{*}{ Tarawa Island } & 1963 & 38 & 8 & 20.8 & 24.4 & \\
\hline & 1968 & 44 & 13 & 28.6 & 67.8 & na \\
\hline & 1973 & 48 & 17 & 35.9 & 36.2 & na \\
\hline & 1978 & 52 & 20 & 39.0 & 16.5 & na \\
\hline & 1990 & 72 & 29 & 40.3 & 3.8 & na \\
\hline Maldives & 1977 & 143 & 34 & 23.6 & & \\
\hline \multirow[t]{2}{*}{ Male', Male' Atoll } & 1985 & 180 & 55 & 30.3 & 31.3 & na \\
\hline & 1990 & 214 & 66 & 30.7 & 1.9 & na \\
\hline Marshall Islands & 1980 & 31 & 12 & 38.2 & & \\
\hline Majur Atoll (excl. U.S. military forces) & 1988 & 43 & 20 & 45.3 & 22.9 & na \\
\hline Mauritius & 1976 & 851 & 134 & 15.7 & & \\
\hline \multirow[t]{2}{*}{ Port Louis district } & 1983 & 1,000 & 134 & 13.4 & -23.0 & 3,838 \\
\hline & 1990 & 1,057 & 133 & 12.6 & -9.0 & 4,737 \\
\hline
\end{tabular}


TABLE 1. Postwar Population Redistribution by Country (Continued)

\begin{tabular}{|c|c|c|c|c|c|c|}
\hline \multirow{2}{*}{$\begin{array}{l}\text { Country and Core Region } \\
\text { Constituent Subdivisions }\end{array}$} & \multirow[b]{2}{*}{ Year } & \multicolumn{2}{|c|}{ Population (thousands) } & \multirow{2}{*}{$\begin{array}{l}\text { Share of } \\
\text { Core }(\%)\end{array}$} & \multirow{2}{*}{$\begin{array}{l}\text { Core - National } \\
\text { Growth Rate } \\
\qquad\left(\times 10^{3}\right)\end{array}$} & \multirow{2}{*}{$\begin{array}{c}\text { GDP per capita (1985 } \\
\text { USD; inter-censal } \\
\text { average) }\end{array}$} \\
\hline & & National & Core & & & \\
\hline 'Seychelles & 1960 & 41 & 16 & 39.5 & & \\
\hline Metropolitan Victoria; Anse aux Pins & 1971 & 53 & 21 & 40.1 & 1.4 & 1,508 \\
\hline and Bel Ambre parishes & 1977 & 62 & 26 & 41.6 & 9.5 & 2,006 \\
\hline Solomon Islands & 1970 & 161 & 35 & 21.9 & & \\
\hline \multirow[t]{2}{*}{ Honiara and Guadacanal provinces } & 1976 & 197 & 47 & 23.7 & 15.5 & na \\
\hline & 1986 & 285 & 80 & 28.1 & 16.3 & na \\
\hline Tonga & 1956 & 57 & 31 & 55.0 & & \\
\hline \multirow[t]{3}{*}{ Tongatpu division } & 1966 & 77 & 48 & 61.9 & 13.6 & na \\
\hline & 1976 & 90 & 57 & 63.7 & 1.6 & na \\
\hline & 1986 & 95 & 63 & 67.3 & 4.6 & na \\
\hline Western Samoa & 1961 & 114 & 49 & 43.4 & & \\
\hline \multirow[t]{3}{*}{ Apia urban area; Northwest Upolu } & 1966 & 131 & 58 & 44.2 & 5.9 & na \\
\hline & 1971 & 147 & 66 & 44.9 & 2.8 & na \\
\hline & 1976 & 152 & 69 & 45.3 & 2.2 & na \\
\hline
\end{tabular}




\section{APPENDIX B: SOURCES}

Source citations for all countries and years not highlighted in Table 1 of Appendix A are in Appendix 1 of Vining (1986). The citations which follow are for new data only. For obvious reasons, original census sources were favored, but recourse was often made to national statistical yearbooks which report census results. What are delicately termed "Estimates" in the statistical sources are not reported. In two cases, however - Thailand and Taiwan - 1992 population registers based on the 1990 censuses were used because available census volumes did not report at the required level of spatial disaggregation.

Algeria:

Argentina:

Bahrain:

Bangladesh:

Bolivia:

Botswana:

Brazil:

Burkina Faso:

Burundi:

Cape Verde:

Chile:

Colombia:

Comoros:
1987: Evolution des populations et des limites communales, 1977-87. Collections statistiques, No. 22. Algiers: Direction des statistiques régionales et de la cartographie (1991).

1991: Censo nacional de población y vivienda 1991, p. 19. Buenos Aires: Instituto nacional de estadística y censo.

1959 and 1965: 4th Census of Population 1965, Table 3, p. 58. Manama: Finance Department.

1971: Statistics of the Population Census 1971, Form 28, p. 161. Manama: Statistical Bureau.

1981: Bahrain Census of Population and Housing 1981, Table 3, p. 2. Manama: Directorate of Statistics.

1991: Preliminary Report of the Population Census of 1991, Appendix B, p. 17. Dacca: Bangladesh Bureau of Statistics.

1950: Censo de la población 1950, p. 31. La Paz: Dirección general de estadística y censos.

1976: Bolivia en cifras 1980, Table 14, p. 35. La Paz: Instituto nacional de estadística.

1992: Censo nacional de población y vivienda 1992, resultados finales, p. 8. La Paz: Ministerio de planeamiento y coordinación.

1991: Population of Towns, Villages and Associated Localities, p.1. Gaborene: Central Statistical Office, Ministry of Finance and Development Planning (1992).

1991: Censo demográfico de 1991: análisos preliminares, Vol. 1, Table 3. Diretoria de pesquisas, fundaçao instituto Brasiliero de geografia e estatistica.

1975 and 1985: Annuaire statistique du Burkina Faso 1988, Table 2.1.1.1, p. 25. Ouagadougou: Institut national de la statistique et de la démographie.

1979 and 1990: Annuaire statistique 1990, Table 1.2 and 1.3, p. 5. Bujumbura: Institut de statistique et d'études économiques du Burundi (1991).

1980: Britannica Book of the Year, 1986. 1990: Britannica Bookof the Year, 1994.

1992: Compendio estadística 1993, Table 121-06, p. 12. Santiago: Instituto nacional de estadísticas.

1985: XV Censo nacional de población, Vol. 1, Table 2, pp. 88, 109 and 157. 1993: Eduardo Bos, personal communication regarding XVI Censo de población y vivienda.

1966 and 1980: Recensement général de la population et de l'habitat, 1980, p. 16. Moroni: Direction de la statistique (1984). 
Congo: $\quad$ 1974: Recensement général de la population 1974, Tome IV, Table 1, p. 7. Brazzaville: Bureau central du recenscement.

1984: Recenscement générale de la population et de l'habitat 1984, Vol. 3, Tome 1, p. 3, Table 200. Brazzaville: Direction des statistiques démographiques et sociales.

Costa Rica: $\quad$ 1973: Censos nacionales de 1973, población, Vol. 1, Table 1, p. 1. San José: Dirección general de estadística y censos (1974).

1984: Censo de población 1984, Table 1, p. 1. San José: Ministerio de gobernación y policia (1986).

Côte d'Ivoire: 1975: Britannica Book of the Year, 1986.

1988: Britannica Book of the Year, 1994.

Cuba:

1981: Annuario demogáfico 1984, Table 2, p. 2. Havana: Instituto de investigaciones estadísticas.

Cyprus:

1946-73: Demographic Report 1991, p. 30, Table 2. Population Statistics, Series 2, Report No, 29. Nicosia: Department of Statistics and Research, Ministry of Finance.

Ecuador: $\quad$ 1990: V Censo de población 1990, resultados definitivos, resumen nacional, Table 2, p. 13. Quito: Instituto nacional de estadística y censos (1991).

Egypt: 1986: Statistical Yearbook 1987, Tables 1, 2 and 3, p. 10. Cairo: Central Agency for Public Mobilisation and Statistics.

El Salvador: $\quad$ 1950: Avance tercer censo de población 1961, Table 1, p. IV. San Salvador: Dirección general de estadística y censos.

1961 and 1971: Cuatro censo nacional de población, cifras prelintinarios, Table 2, p. 2. San Salvador: Dirección General de Estadistico y Censos.

1992: Britannica Book of the Year, 1994.

Fiji:

1966 and 1976: South Pacific Commission, Population of Fiji, Table 11, p. 28. Noumea: South Pacific Commission (1989).

1986: Report of Fiji Population Census, Table 2.7, p. 16. Suva: Bureau of Statistics (1989).

Ghana: 1970 and 1984: Quarterly Digest of Statistics December 1991, Vol. XI, Number 4, Table 94, p. 112 . Accra: Statistical Service.

Greece: 1991: Pragmatikos plethusnmos tes Ellados, Table B, p. 7. Athens, 1991

Guatemala: $\quad$ 1973: VIII censo de población 1973, Vol. 1, Series 3, Table 1, p. 5 . Guatemala City: Dirección general de estadística.

1981: Censo nacional de 1981, Vol. 1, Table 1, p. 37. Guatemala City: Instituto nacional de estadística.

Guinea: $\quad$ 1977: Britannica Book of the Year, 1986.

1983: Britannica Book of the Year, 1991.

Honduras: $\quad$ 1945-74: Anuario estadística 1983, Table 1, p. 19. Tegucigalpa: Dirección de estadística y censos.

1988: Censo nacional de población, Tome 1.

India:

1991: Bose, A., Population of India: 1991 Census Results and Methodology, Table 1, p. 56. Delhi: B. R. Publishing Company. 
Iraq:

Ireland:

Israel:

Jamaica:

Kiribati:

Korea:

Lesotho:

Liberia:

Madagascar:

Malawi:

Malaysia:

Maldives:

Mali:

Marshall Islands:

Mauritania:

Mauritius
1965: Central Statistical Office, General Population Census of 1965. 1977 and 1987: Annual Abstract of Statistics 1988. Baghdad: Central Statistical Organisation, Ministry of Plan.

1986 and 1991: Statistical Abstract 1991, Table 2.4, p. 24. Dublin: Central Statistical Office.

1983: Census of Population and Housing 1983: Selected Results from Complete Enumeration, Table 4, p. 69. Tel Aviv: Central Bureau of Statistics.

1960-82: Statistical Yearbook of Jamaica 1989, Tables 3.1 and 3.3, pp. 89-90. Kingston: The Statistical Institute of Jamaica (1989);

1991: Demographic Statistics 1991, Table (ii), p. (iii). Kingston: Statistical Institute of Jamaica.

1947-78: Report on the 1978 Census of Population and Housing, Vol. II, Table 1.1, p. 26. Bairiki Taraw Kiribati: Ministry of Home Affairs and Decentralisation (1983).

1990: Britannica Book of the Year, 1994.

1985-90: Korea Statistical Yearbook 1991, Table 2, p. 36 . Seoul: National Statistical Office.

1966: Population Census Report, Vol. 1, Table 1, p. 98. Maseru: Bureau of Statistics.

1976 and 1986: Lesotho Statistical Yearbook 1988, Table B.2, p. 19. Maseru: Bureau of Statistics (1990).

1962-84: 1984 Population and Housing Census Summary Population Results, Table 1, p. 11. Monrovia: Ministry of Planning and Economic Affairs (1987).

1966 and 1975: Andrianarivelo Rafrezy Vincent and Randretsa Iarivony, Population de Madagascar. Antanarivo: Ministère de l'enseignement supérieure et de la recherche scientifique (1984). i 966 , data are from a demographic inquiry; 1975 data from a population census.

1966 and 1977: Malazvi Population Census 1977, Final Report, Vol. 1, Table 1.2, p. 1. Zomba: National Statistical Office.

1987: Britannica Book of the Year, 1994.

1991: Britannica Book of the Year, 1994.

1977-90: Statistical Yearbook of Maldives 1990, Table 11-1, p. 10. Male': Ministry of Planning and Environment.

1976: Analyse du recensement de 1976, Vol. III, Table 1, p. 8. Bamako: Ministère du plan (1985).

1985: Annuaire statistique du Mali, Table 1, p. 41. Bamako: Ministère du Plan (1988).

1980 and 1988: Census of Population and Housing 1988 Final Report, Table 3.2, p. 16. Majeru: Office of Planning and Statistics.

1965 and 1977: Recensement genéral de la population 1977, Vol. 2, p. 25. Nouakchott: Direction de la statistique.

-1988: Britannica Book of the Year, 1994.

1976-90: 1990 Housing and Population Census of Mauritius, Vol. II, Table 1, p. 1. Port Louis: Ministry of Economic Planning and Development, 1991. 
Mexico: 1990: Agenda estadística 1990, Table III.1, p. 49. Mexico City: Instiuto nacional de estadística, geografía e informática (1991).

Mongolia: $\quad$ 1963-79: National Economy for the Mongolian People's Republic for the Sixty Years 1921-81, pp. 76-79. Ulan Bator: Central Statistical Board.

Morocco: 1960-82: Findlay, A. M., and Findlay, A. F. 1986. Regional economic disparities and population change in Morocco. Scottish Geograhical Magazine 102: $29-41$.

Mozambique: 1960 and 1970: Statistical Abstract 1972.

1980: First Population Census of Mozambique, 1980, Table 2. Maputo: Conselho Coordenador de Recenseamente.

Myanmar: 1973 and 1983: Statistical Yearbook 1989, p. 10. Yangon: Central Statistical Organisation.

Namibia: 1970-91: Statistical Abstract 1992, Table 2.1. Windhoek: Central Statistics Office, National Planning Commission.

Nepal: $\quad 1981$ and 1991: Statistical Yearbook of Nepal 1993, Table 1.2, pp. 5-6. Kathmandu: Central Bureau of Statistics.

Nicaragua: 1950-70: Censos nacionales 1971, Vol. 1, p. III. Managua: Banco central de Nicaragua (1974).

Niger: 1960-88: République du Niger, Direction de la statistique et de la démographie, Annuaire statistique, "Séries Longues," 1991, Table 2.02 and 2.07. Niamy: Ministère du plan.

Panama: 1990: Indicadores economicos y sociales de Panama 1981-1990 y primer semestre de 1991, Table II, p. 3. Panama City: Dirección de estadística y censo (1991).

Papua New Guinea: 1966-80: A Crosbie Walsh, Inter-provincial migration in Papua Nezv Guinea, Tables $1 \mathrm{a}$, p. 13 and $1 \mathrm{~b}$, p. 14.

1980 National Population Census Reserch Monograph Number 3. Port Moresby: National Statistical Office (1985).

1990: Britannica Book of the Year, 1994.

Paraguay: $\quad$ 1972-82: Annuario estadistico del Paraguay 1984, Table 2.1.2, p. 27;

1992: Censo nacional de población y vivienda 1992 (cifras provisorias), Table 2,

p. 3. Asunción: Dirección general de estadística, encuestas y censos.

Peru:

1993: Creciniento y distribucion de la Población (análisis de cifras preliminares), Table 5, p. 25. Lima: Instituto Nacional de Estadística e informática, Dirección tecnica de demografía y estudios sociales.

Philippines: $\quad$ 1990: Philippines Statistical Yearbook 1991, Table 1.1, pp.1-4. Manila: Republic of Philippines National Statistical Coordination Board.

Portugal: $\quad$ 1990: Portugal Ent Numeros, 1991, p. 7. Lisbon: Instituto Nacional de Estatistica.

Rwanda: $\quad$ 1978: Britannica Book of the Year, 1986.

1991: Britannica Book of the Year, 1994.

Seychelles: $\quad$ 1960-77: 1977 Census Report, Table 13.6, p. 48. Mahe: Republic of Seychelles (1978). 
Sierra Leone: 1985: Gleave, M. 1988. Changing population distribution in Sierra Leone, 1974-85. Geography 73: 351-54.

Solomon Islands: 1970-86: Report on the Census of Population 1986, Report 2, A, Basic Information, Basic Table 1, p. 71. Honiara: Statistics Office.

Spain: $\quad$ 1990: Censo de Viviendes 1991, Avance de Resultados, p. 19. Madrid: Instituto Nacional de Estadística (1992).

Sri Lanka: 1991: Population Statistics of Sri Lanka, Table 11, p. 12. Colombo: Population Information Center, Population Division, Ministry of Health and Women's Affairs (1992).

Sudan:

1955/56-83: Saghayroun, A., Farah, A., Ahmed, S., and Kheir, M. 1988. Population and development in the Sudan: The quest for a national policy. Khartoum: Sudan National Population Committee (1988).

1993: Population Census of Sudan 1993 Provisional Results, Table 1. Khartoum: Census Office, Central Bureau of Statistics.

Taiwan: $\quad$ 1986: 1986 Taiwan-Fukien Demographic Fact Book of Republic of China, pp. 30 and 42. Taipei: Ministry of the Interior.

1992: Monthly Statistics of the Republic of China, 320 (September 1992). Taipei: Directorate-General of Budget, Accounting and Statistics.

Tanzania:

1988: 1988 Population Census: Preliminary Report, Table 1, p. 21. Dar es Salaam: Bureau of Statistics, Ministry of Finance, Economics Affairs and Planning.

Thailand: $\quad$ 1992: Key Statistics of Thailand 1993, Table 1.2, p. 4. Bangkok: National Statistics Office, Office of the Prime Minister.

Tonga: 1956-86: Statistical Abstract 1987, Table 6, p. 9. Nuku'alofa: Statistics Department (1988).

Tunisia: $\quad$ 1984: Recensement général de la population et de l'habitat 1984, Vol. 1, Table 3, p. 24. Tunis: Institut national de la statistique.

Turkey: $\quad$ 1985: Genel Naifus Sazimi 1985, Table 6, p. 6. Ankara: Prime Ministry. 1990: 1990 Genel Nüfus Sayimi Idari Bölünüs, Table 6, p. 6. State Institute of Statistics, Prime Ministry. Ankara, 1991.

Uganda: $\quad$ 1969-91: Final Results of the 1991 Population and Housing Census, Table 2. Entebbe: Ministry of Finance and Economic Planning, 1992.

Uruguay: $\quad$ 1985: Recuentos preliminarios VI censo general de población, Table T1, p. 1. Montevideo: Dirección General de Estatdistica y Censo.

Venezuela: $\quad$ 1990: Anuario estadistica de Venezuela 1990, Table 211-01, p. 185. Caracas: Oficina central de estadística e informática.

Vietnam: 1979: Population Census 1979, Table 1, p. 23. Hanoi: General Population Census Central Committee (1982).

1989: Completed Census Results, Vietnam Population Census 1989, Vol. 1, Table 1.1, p. 13. Hanoi: Central Census Steering Committee (1991).

Western Samoa: $\quad$ 1961-76: Census of Population and Housing 1976, Analytical Report, Vol. 2, Tables 2.2 and 2.3, pp. 9-10. Apia: Department of Statistics (1979). 
Zambia:

1980: 1980 Census of Population and Housing Preliminary Report, Table A1, p. 8. Lusaka: Central Statistical Office. (1981).

1990: Britannica Book of the Year 1994.

Zimbabwe:

1969: Statistical Yearbook 1987, Table 2.12, p. 22. Harare: Central Statistical Office (1987).

1982 and 1992: Census 1992 Preliminary Report, Table 2.2. Harare: Central Statistics Office. 
